\title{
買なる週秢の鷄の胸肉と腿仢における粘弾性の比較なら びにてれらにおよぼす飼料へ添加された脂質の影響
}

\author{
渡邊幸夫・後藤信男* \\ 福島紧立会津短期大学，会津若松市 965
}

(1980. 2.1 受付)

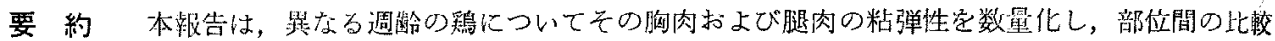
を試みるととむに，飼料一添加した脂質量の水淮がこれら鵎肉の粘弾性に与光る影響を調べたものであ

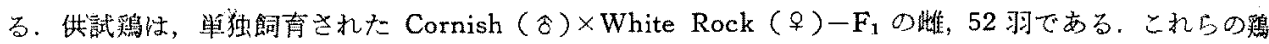
を3群に分けて，大豆白絞油を 0\%，5\%および 10\%含を実験飼料を用いてそれぞれ飼育した。飼育期 閒忙 10,20 および 34 週龄までである。屠殺直後，胸肉と腿肉とを探取し，するやかにポリエチレン製

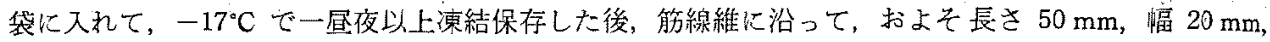
厚さ2 4 mm の切片を得た。これらの切片をダンベル型に整形して試料肉切片とし, 鎖荷重式フート ・レオメータ学用いて $30 \pm 1^{\circ} \mathrm{C}$, 相対湿度 $50 \pm 5 \%$ 条件下で応力緩和試駼（引き伸し距離： $13.5 \mathrm{~mm}$,

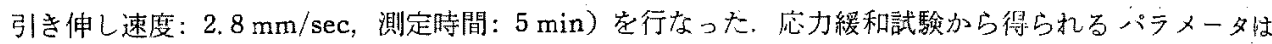
$F_{\max }(\mathrm{gw}), \tau(\mathrm{sec})$ および $S / f_{0}(\%)$ である.結朵は次の通りである，1） $F_{\max }$ 值は，すべての嫍群にお いて腿肉の方が胸肉よりも大きく $(\mathrm{P}<0.01)$, 腿肉社胸肉に比べコシ（伸びに対して強い抵抗空示主性 質）が強い上考元られた，2）脂質無添加飼料で飼育された鷄群では，腿肉に関するて值の方が胸肉の

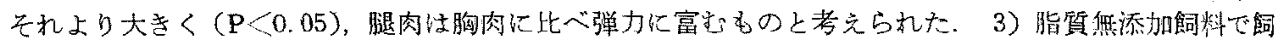

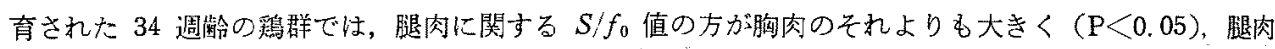
は胸肉に比べ肉の基礎構造が丈夫であると考兵られた４）飼料に添加された脂質量の水潗の違いによ

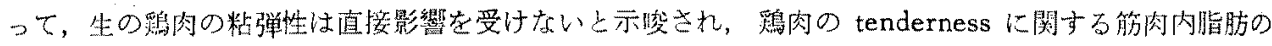
役割は副次的な要因であると考光られた。

日畜会報， $51(8) ： 568-573 ， 1980$
\end{abstract}

食闪の粘弹性や機械的特性证古くから tenderness と いう言菜で表わさ㣗て来ている。鵙肉のかたさ・来らか

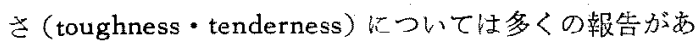
吕が，肉質改善を目的とした研究で山下ら ${ }^{1,2}$ は、プロイ

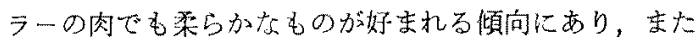
ある程度粗脂肪含最の多い大腿肉訬ないるのに比べ て，風昧に関主る官能評洒がよくなるという結果老得て いる。このことから默闪でも脂肪含量の多い肉と少ない

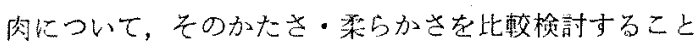

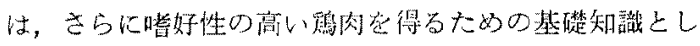
て必慗であると思すれる。

本報告以異なる䓢觜の鴊の胸肉括よび腿肉について，

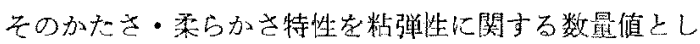

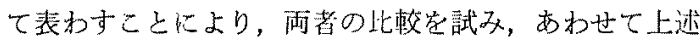

* 現所属：压林水産省冢童衛生試験場， 茨城県筑波䄷林研究団地 305
の観点から飼料に脂貿（大豆白絞澌）添加することに よって得た，脂肪含量の多い肉と少ない肉已に预ける粘 弾性を比較し，脂質添加の影響を調べようとするすのて

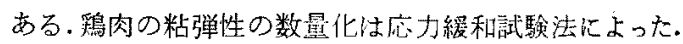

\section{材料および方法}

\section{倛試啋}

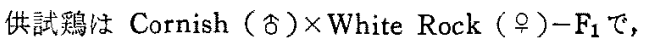
その個体数は 52 である。鵎胸肉の粘弾性は雌雄によっ て異なることが示唆されているので3，謟はすべて雌で ある。これらの鶏を 1 力月龄目に伹作為に 3 群に分け て，以後個別ゲージにて単独飼育した，飼育期間は各群 とも 10,20 および 34 䢙龄までである。

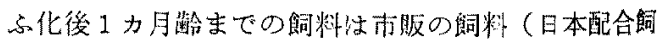
料筴）を用い，常法通りの飼育客行なった。その後4日

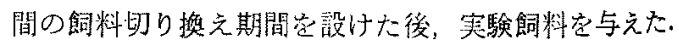


Table 1. Composition of experimental diets (\%).

\begin{tabular}{|c|c|c|c|}
\hline \multirow{2}{*}{ Ingredient } & \multicolumn{3}{|c|}{ Diet } \\
\hline & A & $\mathrm{B}$ & $\mathrm{C}$ \\
\hline Ground corn & 25 & 50 & 60 \\
\hline Defatted soybean & 20 & 21 & 23 \\
\hline Wheat bran & 39 & 20 & 3 \\
\hline Soybean oil ${ }^{\text {a }}$ & 0 & 5 & 10 \\
\hline Wood chips & 2.4 & 0 & 0 \\
\hline Mineral mixture $I^{b}$ & 0.2 & 0.2 & 0.2 \\
\hline Mineral mixture $I^{c}$ & 0.1 & 0.1 & 0.1 \\
\hline Dicalcium phoshate & 0.45 & 0.45 & 0.45 \\
\hline DL-Methionine & 0.05 & 0.05 & 0.05 \\
\hline CF determined & 3.44 & 8.62 & 12.03 \\
\hline $\mathrm{CP}$ calculated & 16.4 & 16.0 & 15.4 \\
\hline TDN calculated & 52 & 71 & 82 \\
\hline
\end{tabular}

CF: crude fat, CP: crude protein, TDN: total digestible nutrient, a: manufactured by Nisshin Seiyu Co., Ltd., b: feed additive for broiler, manufactured by Dawe's Laboratory (Japan), Ltd., c: manufactured by Nippon Zenyaku Kōgyō, Co., Ltd., d: calcium phosphate dibasic.

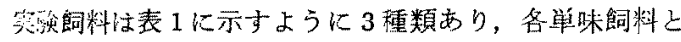
大豆白絞油(日清製油製)上老主成分とするが，粗た九ぱ く質 (CP) はほとんど同じ水準になるようにしてある。 これら3種の5方脂質 (大豆白较油) 無添加解料を $\mathrm{A}$, 脂質 $5 \%$ 添加飼料を B，立大脂䝷 $10 \%$ 添加飼料觉 C と

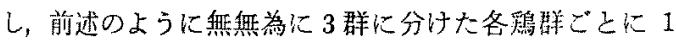
種類ずつこれら实験飼料をそれぞれ与えた、考察の項 で述べるように，鵎肉中の粗脂肪含量は $\mathrm{A} \rightarrow \mathrm{B} \rightarrow \mathrm{C}$ の飼 料の順に多くなるように配跑しである。給期壁は 1 羽・ 1 日当たり 100 $150 \mathrm{~g}$ の航囲で，週齡に応して加減し た、鴊の飼育は11月より翌年の6月まで行ない，飼料 中の脂質が酸敗しないように，数回に分けて实験稖料を 調製した。

供試闪および供試肉の粗脂肪含量:

供試肉は，鵸を屠殺後す多やかに解体して採取した胸 肉 (M. pectoralis profundus) と腿肉 (M. iliotibialis) である、以下，胸肉就よび腿肉と略記する，表 2 に示す 供試肉门の粗脂肪の含堅は SOXHLET 法によった。ただ し本表の值怯各週监の各群ごとに，それぞれ然作為に3 羽選び，その供試肉について測定したものである。

試科洞切片の調製および応力綏和試歌

前述のように採取した供試肉をただちに台木に固定

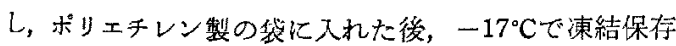

した，以後の試料肉切片の調製（切片の寸法）やフード ・レオメータ (田葉井製) に上る心力紘和試験法（引き 伸し速度: $2.8 \mathrm{~mm} / \mathrm{sec}$,引伸し距離: $13.5 \mathrm{~mm}$, 測定 時間： $5 \mathrm{~min}$ ) 扰よび得られる応力綏和出線からの粘弹 性解析法は前報》と同じである。笖力緩和測定から得ら れる情報は $F_{\max }(\mathrm{gw}) ， \tau(\mathrm{sec})$ および $S / f_{0}(\%)$ で る.これらのパラメータの性格および肉質に対して持つ 意昧は既報泉の通りである。測定に供した試料肉切片数 は各個体につきお扎よそ3〜7であり，これらの測定值 を平均したもの它個体の值とした，表 3 に示寸各群の各 パラメータ值は個体の值から求めた平均値であり，標準

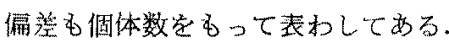

結 果

I. 供試肉心粗脂肪含量

Table 2. Crude fat content (\%) in samp.e meat.

\begin{tabular}{|c|c|c|c|c|}
\hline \multirow{2}{*}{ Portion } & \multirow{2}{*}{ Diet } & \multicolumn{3}{|c|}{ Age (Week) } \\
\hline & & 10 & 20 & 34 \\
\hline \multirow{3}{*}{ Breast meat } & A & 1.00 & 1.04 & 1.39 \\
\hline & $\mathrm{B}$ & 1.07 & 1.56 & 1.83 \\
\hline & $\mathrm{C}$ & 1.15 & 1.85 & 1.96 \\
\hline \multirow{3}{*}{ Thigh meat } & A & $\ldots$ & 1.17 & 2.72 \\
\hline & B & $\cdots$ & 1.73 & 3.69 \\
\hline & $\mathrm{C}$ & $\ldots$ & 2.01 & 3.50 \\
\hline
\end{tabular}

表 2 に示すように供試闪の粗脂肪含星は邀修が增すに つれて僅がず增加する傾们が見られ，その含量は脂質

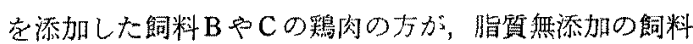
A の鴊肉よりも多くなることがうかがわれる。

\section{II. 胸肉と腿肉比ける粘弹性の比故}

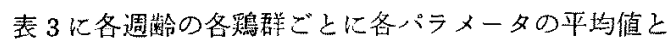

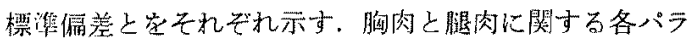
メー夕の値比較方るため，各個体についての平均値を 基化分散分析による有意接検定を行なった。その結果， $F_{\max }$ 值については A，B およびCの飼料の鷂群すべて において，腿肉の方が胸肉よりも明らが大であった。 肉質に対して $F_{\max }$ が持つ意味は，コシ(腰，body：伸 びに対して強い抵抗を示す性質)の強弱落表わす尺度で あるので，腿肉は胸肉よりるコシが強いことが数量的に

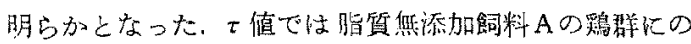
叭，腿肉の方が胸肉よりも大きい，值の大小加ら弾力 の程度它推澌できるので，脂質餂添加飼料 Aの舀群で 


\section{渡遥・後藤}

Table 3. Comparison of means on parameters of viscoelastic properties between breast and thigh meat in the chickens of different ages.

\begin{tabular}{|c|c|c|c|c|c|c|}
\hline \multirow{2}{*}{$\begin{array}{c}\text { Age } \\
(\text { Week })\end{array}$} & \multirow{2}{*}{ Diet } & \multirow{2}{*}{$\begin{array}{c}\text { No. of } \\
\text { Chickens }\end{array}$} & \multirow{2}{*}{$\begin{array}{l}\text { No. of } \\
\text { measure- } \\
\text { Ments }\end{array}$} & \multicolumn{3}{|c|}{ Parameters } \\
\hline & & & & $F_{\max }(g w)$ & $\tau(\mathrm{sec})$ & $S / f_{0}(\%)$ \\
\hline \multirow{3}{*}{10} & A & 5 & 17 & $22.31 \pm 9.59$ & $9.93 \pm 9.42$ & $26.38 \pm 5.27$ \\
\hline & B & 7 & 40 & $23.49 \pm 4.66$ & $12.49 \pm 6.37$ & $22.53 \pm 4.29$ \\
\hline & $\mathrm{C}$ & 7 & 48 & $23.02 \pm 6.75$ & $12.52 \pm 4.94$ & $22.96 \pm 4.03$ \\
\hline \multirow{3}{*}{20} & A & $\begin{array}{c}4 \\
(6)\end{array}$ & $\begin{array}{c}20 \\
(39)\end{array}$ & $\begin{array}{l}25.75 \pm 10.10^{\mathbf{a}} \\
\left(82.35 \pm 21.81^{3}\right)\end{array}$ & $\begin{array}{c}6.41 \pm 3.86^{8} \\
(17.90 \pm 4.01 \mathrm{~s})\end{array}$ & $\begin{array}{c}23.55 \pm 3.88 \\
(24.08 \pm 3.36)\end{array}$ \\
\hline & $\mathrm{B}$ & $\stackrel{4}{(6)}$ & $\begin{array}{c}25 \\
(37)\end{array}$ & $\begin{array}{c}24.12 \pm 4.39^{b} \\
\left(84.79 \pm 16.33^{b}\right)\end{array}$ & $\begin{array}{c}13.46 \pm 5.72 \\
(12.27 \pm 1.57)\end{array}$ & $\begin{array}{c}27.74 \pm 6.80 \\
(23.72 \pm 4.31)\end{array}$ \\
\hline & $\mathrm{C}$ & $\begin{array}{c}5 \\
(6)\end{array}$ & $\begin{array}{c}50 \\
(54)\end{array}$ & $\begin{array}{l}27.39 \pm 3.99^{c} \\
\left(89.60 \pm 18.44^{c}\right)\end{array}$ & $\begin{array}{c}12.57 \pm 2.39 \\
(15.94 \pm 5.68)\end{array}$ & $\begin{array}{c}27.34 \pm 6.24 \\
(23.27 \pm 2.02)\end{array}$ \\
\hline \multirow{3}{*}{34} & A & $\begin{array}{l}3 \\
(6)\end{array}$ & $\begin{array}{c}9 \\
(34)\end{array}$ & $\begin{array}{c}30.15 \pm 10.90^{d} \\
\left(101.55 \pm 16.96^{d}\right)\end{array}$ & $\begin{array}{c}5.48 \pm 2.16^{\mathrm{h}} \\
\left(11.34 \pm 1.93^{\mathrm{h}}\right)\end{array}$ & $\begin{array}{c}16.72 \pm 1.81^{1} \\
\left(25.48 \pm 4.87^{1}\right)\end{array}$ \\
\hline & $\mathrm{B}$ & $\begin{array}{c}4 \\
(4)\end{array}$ & $\begin{array}{c}16 \\
(23)\end{array}$ & $\begin{array}{c}14.24 \pm 5.62^{\mathrm{e}} \\
\left(96.10 \pm 27.87^{\mathrm{e}}\right)\end{array}$ & $\begin{array}{c}10.07 \pm 2.73 \\
(12.86 \pm 3.74)\end{array}$ & $\begin{array}{c}23.65 \pm 7.27 \\
(21.51 \pm 3.62)\end{array}$ \\
\hline & $\mathrm{C}$ & $\begin{array}{c}5 \\
(5)\end{array}$ & $\begin{array}{c}18 \\
(32)\end{array}$ & $\begin{array}{c}27.93 \pm 12.75^{\mathrm{f}} \\
\left(83.44 \pm 27.02^{f}\right)\end{array}$ & $\begin{array}{l}14.05 \pm 9.94 \\
(14.70 \pm 4.83)\end{array}$ & $\begin{array}{c}22.43 \pm 9.67 \\
(22.24 \pm 3.15)\end{array}$ \\
\hline
\end{tabular}

Each value represents mean \pm S. D. ${ }^{8}$ Figures in parentheses show values obtained from thigh meat. $a, b, c, d, e, t$ Significant difference between these two values $(P<0.01)$. $\quad, h$,iSignificant difference between these two values $(P<0.05)$. "See Table 1 .

は，ての腿肉は胸肉に比らべて，より固体（弾性体）に 近い粘弾性体であって, 弹力に富さものと推察される.

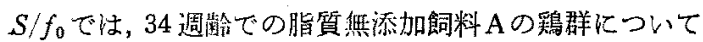

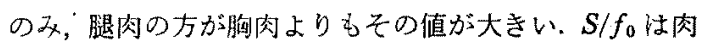
灰形らくる基礎構造の丈夫文度合を意味するものと考 えられるので,このばあいについて筋線維や結合組織に おける網目構造（分子間架橋による）を相対的に見れば， 腿肉の方が匈肉よりもしっかりしていると思われる。
III，週紫抢よび脂質添加飼料による影響

1. 胸肉について

週龄や飼料のちがいによって，胸肉の粘弹性に差異が

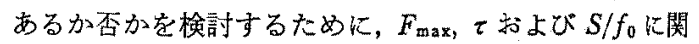
して枝分れ分類による分散分析到を行なった．表 4 にそ の分散分析表を示す．この結果，これらのパラメータ すべてについて，週齢内飼料内個体内測定值（Within Chicken）の分散に対する週㣪内飼料内個体間測定值

Table 4. Analysis of variance by nested classification of parameters in breast meat on the effect of ages and dietary fat levels.

\begin{tabular}{|c|c|c|c|c|c|c|c|c|c|c|}
\hline \multirow{2}{*}{ Source } & \multicolumn{4}{|c|}{$F_{\max }$} & \multicolumn{3}{|c|}{$\tau$} & \multicolumn{3}{|c|}{$S / f_{0}$} \\
\hline & $\mathrm{DF}$ & SS & MS & Fcal & SS & MS & Fcal & SS & MS & Fcal \\
\hline $\begin{array}{c}\text { Age } \\
\text { (Week) }\end{array}$ & 2 & 494.61 & 247.31 & 0.61 & 91.60 & 45.80 & 0.29 & 794.93 & 397.47 & 3.03 \\
\hline Diet & 6 & 2449.74 & 408.29 & 1.44 & 947.32 & 157.89 & 0.86 & 287.45 & 131.24 & 0.78 \\
\hline Chicken & 36 & 10211.97 & 283.67 & 2. $16^{* *}>F_{198}^{86}$ & 6616.06 & 183.78 & $1.54^{*}>F_{198}^{86}$ & 6081.25 & 168.92 & $2.11^{* *}>F_{198}^{98}$ \\
\hline $\begin{array}{l}\text { Within } \\
\text { Chicken }\end{array}$ & 198 & 26013.79 & 131.38 & & 23614.99 & 119.27 & & 15823.69 & 79.92 & \\
\hline Total & 242 & 39170.11 & & & 31269.97 & & & 23487.32 & & \\
\hline
\end{tabular}

DF: degree of freedom, SS: sum of square, MS: mean square, Fcal : variance ratio, $F_{B}^{2}(0.01)=10.92$, $\mathrm{F}_{8}^{2}(0.05)=5.14, \mathrm{~F}_{86}^{6}(0.01)=3.35, \mathrm{~F}_{86}^{6}(0.05)=2.36, \mathrm{~F}_{198}^{36}(0.01)=1.73, \mathrm{~F}_{198}^{36}(0.05)=1.48 \quad * * \mathrm{P}<0.01$, $* \mathrm{P}<0.05$. 
鴹胸肉と腿肉注ける粘弾性比較

Table 5. Analysis of variance by nested classification of parameters in thigh meat on the effect of ages and dietary fat levels.

\begin{tabular}{|c|c|c|c|c|c|c|c|c|c|c|}
\hline \multirow{2}{*}{ Source } & \multicolumn{4}{|c|}{$F_{\max }$} & \multicolumn{3}{|c|}{$\tau$} & \multicolumn{3}{|c|}{$S / f_{0}$} \\
\hline & DF & SS & MS & Fcal & SS & MS & Fcal & SS & MS & Fcal \\
\hline $\begin{array}{l}\text { Age } \\
\text { (Wee) }\end{array}$ & 1 & 2817.99 & 2817.99 & 1.65 & 388.88 & 388.88 & 2.11 & 23.29 & 23.29 & 0.34 \\
\hline Diet & 4 & 6830.80 & 1707.70 & 1.50 & 738.82 & 184.71 & 1.64 & 276.85 & 69.21 & 0.84 \\
\hline Chicken & 27 & 30801.29 & 1140.79 & 1.28 & 3040.68 & 112.62 & $2.43^{* *}>\mathrm{F}_{186}^{27}$ & 2229.21 & 82.56 & $3.26^{* *}>\mathrm{F}_{186}^{27}$ \\
\hline $\begin{array}{l}\text { Within } \\
\text { chicken }\end{array}$ & 186 & 166057.03 & 892.78 & & 8623.10 & 46.36 & & 4707.73 & 25.31 & \\
\hline Total & 218 & 206507.11 & & & 12791.48 & & & 7237.08 & & \\
\hline
\end{tabular}

$\mathrm{DF}$ : degree of freedom, SS: sum of square, Fcal: variance ratio, MS: mean square, $\mathrm{F}_{4}^{1}(0.01)=21.20$, $\mathrm{F}_{4}^{1}(0.05)=7.71, \mathrm{~F}_{27}^{4}(0.01)=4.11, \mathrm{~F}_{27}^{4}(0.05)=2.73, \mathrm{~F}_{186}^{27}(0.01)=1.84, \mathrm{~F}_{186}^{27}(0.05)=1.54, \quad * * \mathrm{P}<0.01$, $* \mathrm{P}<0.05$.

(Chicken)の分散の比に関しての六有意差が詳好られ， そくに $F_{\max }$ と $S / f_{0}$ については $1 \%$ 水準で有意であっ た.したがって，週龄や飼料中での脂質水淮の違いによ っては，胸肉の粘弾性に差異がないが，個体間について はその差加哂められたことになる。

2. 腿肉について

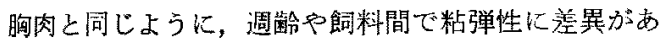
るか否かを確めるために枝分れ分類による分散分析 ${ }^{5}$ を 行なった. 表 5 にその分散分析表を示すようにてと $S / f_{0}$ Kついてのみ，䓢龄内飼料内個体内測定值 (Within Chicken) の分散に対方週㢣内飼料内個体間測定值 (Chicken) の分散の比は有意であったが，その他に関し ては認められなかった。

以上の結果からすれば，本研究における程度の㮰龄の 違いや飼料入添加した脂質量の差買は，生の胸闪および 腿肉の粘弾性に影響を与えないことになる。

\section{考察}

胸肉と腿肉との糙弾性パラメータ值の上較から, 胸闪 性退肉上り来桑らかいという経驗的事実と一致した絬果 加得られたが，週跉や飼料の違いについては統計的に灰 て差が認められなかった。しかし週龄を経るにつれて脂 質無添加飼料Aの鵴群では，乙の胸肉飞関してておよび $S / f_{0}$ 值の減少する傾向が見られる。このことについて は慎重に解釈しなければならないが，既報むで述べたこ れらパラメータの性格をさらに詳細に豫討すれば，以下 の上らになる。值の減少は，肉がより液体に近い粘弹 性体に変わりゆくことを意味するので，この通程に相心 して汃たさ・柔らかさ特性す推移すると思われる。 $\tau$ は

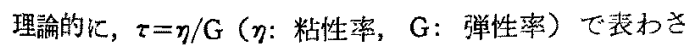

れ，一部の食品ではて值の大小とそのかたさ・乘らかさ 乙の関連が知られている6 ${ }^{6}$. これらのことを基に食肉に ついて推諭すれば， 2 值が小から大になるにつれて，柔

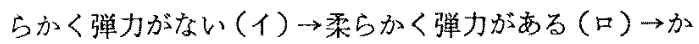
たく弾力がある(ハ)上いう知印の向きに肉質が变わる ものと思われる．とくに嗂胸肉のばあいには一般に柔ら かい（ $\tau$ 值が小さい）ので（イ）から（口）の範用に該

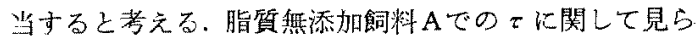
れる傾句は，(品) $\rightarrow(1)$ なることを示すと考えられ，こ のことから週鈢を経るとともに弾力にそしい（相対的に Z゙てGが大きい)胸肉になると推察される. $S / f_{0}$ 值によ る食肉の評価は弾力の有無に関連するものであっで， この值が大から小になるにつれて弾力にそしくなると考 えられる、したがって，脂質然添加飼料Aでの胸肉に関 するパラメータの内容は一致して，本実験では週齿令経

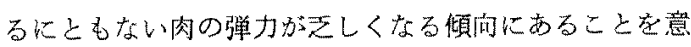
师するものと推諭される。

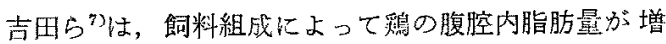
減し，TDN（可消化萑分総量）を下げることおよび CP 空增加させることは，脂肪を分解して減少させる效 果があると報告している。 また腹腔内脂肪量と体脂肪と

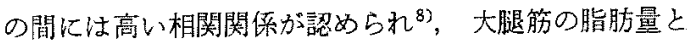
腹腔内脂肪搳との間にも高度な相関の存在が確諗2 さ れている．乙れらの報告から飼料組成によって，鵎肉の 脂肪含星は影響を受けることがわかる，本研究では脂肪

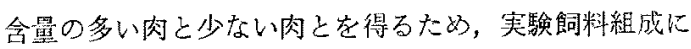
おいて CPを活とんど同じにしたが，TDNには3水等 学設けた。したがって表1からわかるように，A $\mathrm{A} \rightarrow \mathrm{B} \rightarrow \mathrm{C}$ の飼䉼の順に脂肪含量の多い䁌肉汃得られるように設定 してある。しかしながら胸闪抎よび腿肉ともその粘弾性 
に関して飼料閒で差が認めら机なかったことから，脂肪 合量の多い肉と少ない肉とでは，そのかたさ・委らかさ に差異がないものと推察される。これは以下のこと记起 因するものと考元る。

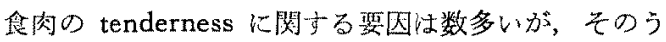
ち最も本質的な要园のひとつとしては，死後の筋肉にお ける収繀，短縮 (contraction, shortening) ${ }^{9-12)}$ 户筋原線 維での小片化 (fragmentation) ${ }^{13-15}$ )がある．羊肉の脂肪 と tencerness との関連についての研究到によれば, 皮 下脂肪および筋肉内脂肪の役制は，泠却による筋肉の短 縮を抑元る機能であるという．脂肪が断熱作用をはたす ので筋肉内部温度が急速には降下しないというむのであ

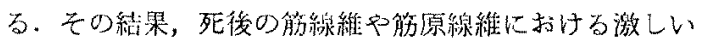
短緶が抑制される。これは死後の筋肉における筋節の長 短が tenderness 汇閔連するとした LOCKER量定始めとす る多くの報告の結果と一致するものである。しかしなが ら，羊肉と鷄肉とではその脂肪含㱏が異なり，鵎肉は脂 肪含量が少ないので，前述のようにかたさ・柔らかさ特 性に刘する脂肪の効果が得られないものと思われる。し たがって，tenderness に刘する脂肪の役割は副次的なも のと考えるのが妥当と思われる。

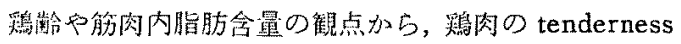
を検討した報告恃数少ないが，WANGEN と SKALA et al. ${ }^{17}$ は白レダ (4〜18 月龄) の加熱肉について, Allo-Kramer shear press 法により調べたところ，胸筋では熖輸によ る梹がなかったが，腿肉では認められ， shear value は

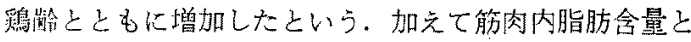
shear value の傾向との間には関連がないと述べている. STRANDINE et al. ${ }^{18)}$ 性生拉よび加熱肉について WarnerBratzler 法により調べたところ，鶂肉の tenderness と その脂肪含最との間には㥵関が䋇いと報告している。

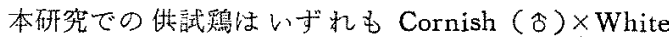
Rock (ๆ) - $F_{1}$ の雌であり，实験飼料を除いて同一条件

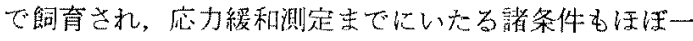
定である。それにるかかからず，生の胸肉と腿肉との粘 弾性に関して個体差が認的られた，それらの部位の生体 検測が考案され，買伝率が推定できるならば，粘弾性を 指標として退抜し，柔らかな肉あるいはかたい肉を持つ 舀を育種することも可能と思われる。そしてこの代あ い,フード・レオメータによる粘弾性の測定は，試料肉
が小片ですをことと相とるなって有力な手段となるであ ろう.

本研究を行なうに当たり有益なご助言とご䧸力下され た福島景立会津短期大学 成田 健氏ならびに東北大学 農学部 藤本健四郎氏に深謝致します。

本研究は昭和 47 年度文部省科学研 究費（課題番号 776210）の補助堂受けな.

\section{文献}

1）山下近男 - 石本佳之・目加田博行 ・海老沢 昭二 ・ 祄茾武彦・野中 進, 家禽誌, 13: 14-18, 1976.

2）山下近男 - 石本佳之・山田卓郎・目加田描行 ・ 海 老祄昭二，家禽会誌，12：78-82. 1975.

3）渡辺幸夫・後藤信男，日畜会報， 50：694-699. 1979.

4）渡辺萃夫・後藤信男，日畜会報，50：363-368。 1979.

5）烟村又好・奥野忠一・津村善郎共訳，統計的方法， スネデカー・コクラン，原書第 6版，272-280. 岩 波辈店. 東京. 1975 .

6）曾根敏䵇，食品の粘稠性，110-111。光琳書院. 東 京. 1966.

7) Yoshida, M., H. Hoshir and H. Morimoto, Japan Poultry Sci., 7: 166-175. 1970.

8）吉明実・星井 博・森本 宏, 家离会誌，6： 89-96. 1969 .

9) Locker, R. H., Food Res,, 25: 304-307. 1960.

10) Smith, Jr. M. C., M. D. Judge and W. J. Stadel MAN, J. Food Sci., 34: 42-46. 1969.

11) Krose, A.A., J. Food Sci., 35: 577-581. 1970.

12) Whiting, R.C. and J.F. Richards, J. Food Sci., 40: 960-963. 1975.

13) Takahashi, K., T. Fukazawa and T. Yasui, J. Food Sci., 32: 409-413. 1967.

14) Fukazawa, T. and E. J. Briskey, J. Food Sci, 34: 606-610. 1969.

15) SAYRE, R.N., J. Food Sci., 35: 7-10. 1970.

16) Smith, G.C., T. R. Dutson, R. L. Hoste tler and Z. L. Carpenter, J. Food Sci., 41: 748-756. 1976.

17) Wangen, R. M. and J.H. Skala, J. Food Sci., 33: 613-616, 1968

18) Strandine, E. J., C. H. Koonz and J. M. Ramsborтом, J. Anim. Sci., 8: 483-494. 1949. 


\title{
Comparison of Viscoelastic Properties of Breast and Thigh Meat and Effect of Dietary Fat Levels on Their Properties in the Chickens of Different Ages
}

\author{
Yukio Watanabe and Nobuo GotoH \\ Aizu Junior Collage of Fukushima Prefecture, \\ Aizuwakamatsu-shi 965
}

The purpose of this paper is to compare the viscoelastic properties between breast and thigh meat in the chickens of different ages by means of stress relaxation test, and to investigate the effect of dietary fat levels on their meat. The chickens used were Cornish $\times$ White Rock raised in individual wire cages. The number of chickens used was 52 in total, and they were all females. They were divided into 3 groups, and fed with the experimental diet containing $0 \%, 5 \%$ and $10 \%$ soybean oil, respectively. The experimental periods were 10, 20 and 34 weeks from day old. Just after slaughter, the breast meat ( $M$. pectoralis profundus) and the thigh meat ( $M$. iliotibialis) were removed. They were immediately put into polyethylene bag, and were kept at $-17^{\circ} \mathrm{C}$ at least for 24 hours. Several pieces ( $50 \mathrm{~mm}$ in length, $20 \mathrm{~mm}$ in width and $2 \sim 4 \mathrm{~mm}$ in thickness) were taken from each chicken meat by a microtome in such a way that long axis of each piece was parallel to the direction of muscle fibers. Then, these pieces were stamped out with a dumbell-shaped apparatus. The stress relaxation measurement of these samples was carried out with a chainomatic balance Food Rheometer (Tabai Co., Ltd.). These samples were stretched $13.5 \mathrm{~mm}$ at a speed $2.8 \mathrm{~mm} / \mathrm{sec}$ and were kept for $5 \mathrm{~min}$ in a chamber with $50 \pm 5 \%$ of relative humidity at $30 \pm 1{ }^{\circ} \mathrm{C}$. The parameters obtained from stress relaxation test were $F_{\max }(\mathrm{gw}), \tau(\mathrm{sec})$, and $S / f_{0}(\%)$. The following imformations were obtained. 1) $F_{\max }$ value was larger in thigh meat than in breast meat in each group $(P<0.01)$, therefore, thigh meat seemed to be stronger than breast meat as to Koshi (Body), 2) $\tau$ value of chicken fed with soybean oil free diet was larger in thigh meat than in breast meat $(P<0.05)$, the thigh meat seemed to be more elastic than the breast meat. 3) In the age of 34 weeks old, $S / f_{0}$ value of chicken fed with soybean oil free diet was larger in thigh meat than in breast meat $(\mathrm{P}<0.05)$, therefore, the structure of the thigh meat seemed to be firmer than that of the breast meat. 4) The result of this experiment suggested that the viscoelastic properties of raw breast and thigh meat of chickens were not affected directly by the dietary fat levels. The role of intramuscular fat on chicken meat tenderness seemed to serve as secondary factor.

Jpn. J. Zootech. Sci., 51 (8): 568-573, 1980 